\title{
PENGOLAHAN INFORMASI DAN PERSEPSI KONSUMEN DI ERA REVOLUSI INDUSTRI 4.0
}

\author{
Kaskodjo Adi \\ Progam Studi Ilmu Administrasi Niaga \\ Sekolah Tinggi Ilmu Administrasi Pembangunan Jember \\ *Email: kaskodjoadi@gmail.com
}

\begin{abstract}
ABSTRAK
Revolusi industri 4.0 merupakan fase revolusi teknologi yang mengubah cara beraktivitas manusia dalam skala, ruang lingkup, kompleksitas, dan transformasi dari pengalaman hidup yang sebelumnya. Prinsip dasar revolusi industri 4.0 adalah menggabungkan mesin, alur kerja, dan sistem dengan menerapkan jaringan cerdas di sepanjang rantai dan proses produksi. Hal ini bertujuan untuk mengendalikan satu sama lain secara mandiri. Perkembangan teknologi yang pesat akan mendorong perubahan perilaku masyarakat, dan peningkatan kebutuhan akan mendorong berubahnya dan terciptanya peluang bisnis dan pekerjaan baru. Perubahan dan peluang bisnis yang baru didorong dengan perkembangan penggunaan internet. Dimana peluang ini juga disadari oleh para pelaku bisnis untuk memanfaatkan internet dalam proses berbisnis. Penggunaan internet dalam proses berbisnis akan terus mengalami perkembangan. Mulai dari pertukaran informasi secara elektronik ke aplikasi strategi bisnis, pemasaran, penjualan, hingga pelayanan pelanggan. Internet juga akan mendukung komunikasi dan kerja sama global antara karyawan, konsumen, penjual, dan rekan bisnis yang lainnya. Selain itu, internet juga memungkinkan orang dari suatu organisasi atau lokasi yang berbeda dapat bekerja sama sebagai satu tim virtual untuk mengembangkan, memproduksi, memasarkan, dan memelihara produk atau pelayanan.
\end{abstract}

Kata kunci : Revolusi, Industri, Bisnis 


\section{A. Analisis Situasi}

Perilaku

konsumen

merupakan studi tentang proses pengambilan keputusan pada individu, kelompok, organisasi, ataupun masyarakat luas untuk menggunakan atau tidak menggunakan produk (barang, jasa, ide). Pemahaman perilaku konsumen bagi pemilik usaha kecil (home industri) berperan sebagai dasar kegiatan penyusunan dan evaluasi strategi pemasaran untuk mencapai target volume dan nilai pemasaran yang telah ditentukan. Bagi pemilik usaha kecil (home industri), pemahaman perilaku konsumen berperan sebagai dasar penetapan kualitas dan kuantitas yang berorientasi tren terkini yang disukai oleh konsumen.

Pengetahuan konsumen dapat memengaruhi keputusan pembelian, apa yang dibeli, berapa banyak yang dibeli, dimana membeli, dan kapan membelinya bergantung pada pengetahuan konsumen mengenai hal-hal tersebut.

Sebelum melakukan pembelian, seorang konsumen akan melakukan sejumlah proses yang mendasari pengambilan keputusan. ia akan membeli suatu produk sebagai solusi atas permasalahan yang dihadapinya. Tanpa pengenalan masalah yang muncul, ia tidak dapat menentukan produk yang akan dibeli. Setelah memahami masalah, konsumen akan termotivasi untuk mencari informasi. Proses mencari informasi dapat berasal dari dalam memori dan berdasarkan pengalaman orang lain.

Setelah mendapat berbagai macam informasi, konsumen akan mengevaluasi alternatif yang ada. Setelah itu, ia membuat keputusan pembelian. Kadang-kadang waktu yang dibutuhkan antara membuat keputusan pembelian dan menciptakan pembelian yang aktual tidak sama disebabkan adanya hal lain yang perlu dipertimbangkan.

Dengan pemikiran diatas, maka hubungan dunia usaha kecil now Industri) dengan revolusi industri 4.0, mengikuti perkembangan teknologi yang sangat cepat dan memanfaatkan teknologi Informasi dan Komunikasi bagi fasilitas lebih dan serba canggih untuk proses evaluasi tidak hanya 
berakhir pada tahap pembuatan keputusan pembelian. Setelah membeli produk, konsumen kan melakukan evaluasi produk tersebut sesuai dengan harapannya. Dalam hal ini terjadi kepuasan dan ketidakpuasan konsumen. Konsumen akan puas ke produk tersebut sesuai dengan harapannya dan ia akan meningkatkan permintaan produk pada masa depan. Sebaliknya, konsumen merasa tidak puas jika produk tersebut tidak sesuai dengan harapannya dan hal ini akan menurunkan permintaan konsumen pada masa depan.

Tingkat kepuasan pelanggan selalu berkaitan dengan dan bergantung pada mutu suatu produk yang dihasilkan oleh pemilik usaha kecil Home industri). Suatu produk dikatakan bermutu apabila produk tersebut memenuhi kebutuhan penggunanya atau pelanggannya.

Tidak semua stimulus mendapat perhatian karena konsumen melakukan pengolahan informasi Pengolahan Informasi terjadi ketika salah satu panca indra konsumen menerima Input dalam bentuk stimulus. Stimulus merupakan sesuatu yang diterima panca indra kemudian diolah oleh otak manusia yang akan menjadi suatu informasi. Stimulus pada konsumen dapat berbentuk produk, nama merek, kemasan, iklan, dan nama produsen Informasi yang didapat oleh seorang konsumen tentu tidak didapat secara instan, total perlu melalui berbagai tahapan, yaitu paparan, perhatian, pemahaman penerimaan, dan retensi.

Pemaparan merupakan proses penerimaan stimulus oleh pancaindra yang akan menimbulkan suatu sensasi Sensasi merupakan respons langsung dan cepat dari pancaindra terhadap stimulus yang datang, Sensasi dipengaruhi oleh dua faktor, yaitu ambang absolut jumlah minimal energi stimulus yang diperlukan konsumen dan ambang berbeda. Perhatian merupakan perceptual selection yang juga dipengaruhi oleh dua faktor, yaitu faktor pribadi dan faktor stimulus. Faktor ini meliputi ukuran, warna, intensitas, kontras, posisi, petunjuk. gerakan, kebauran, isolsi, perubahan gambar, pesan menarik, dan stimulus yang disengaja. 


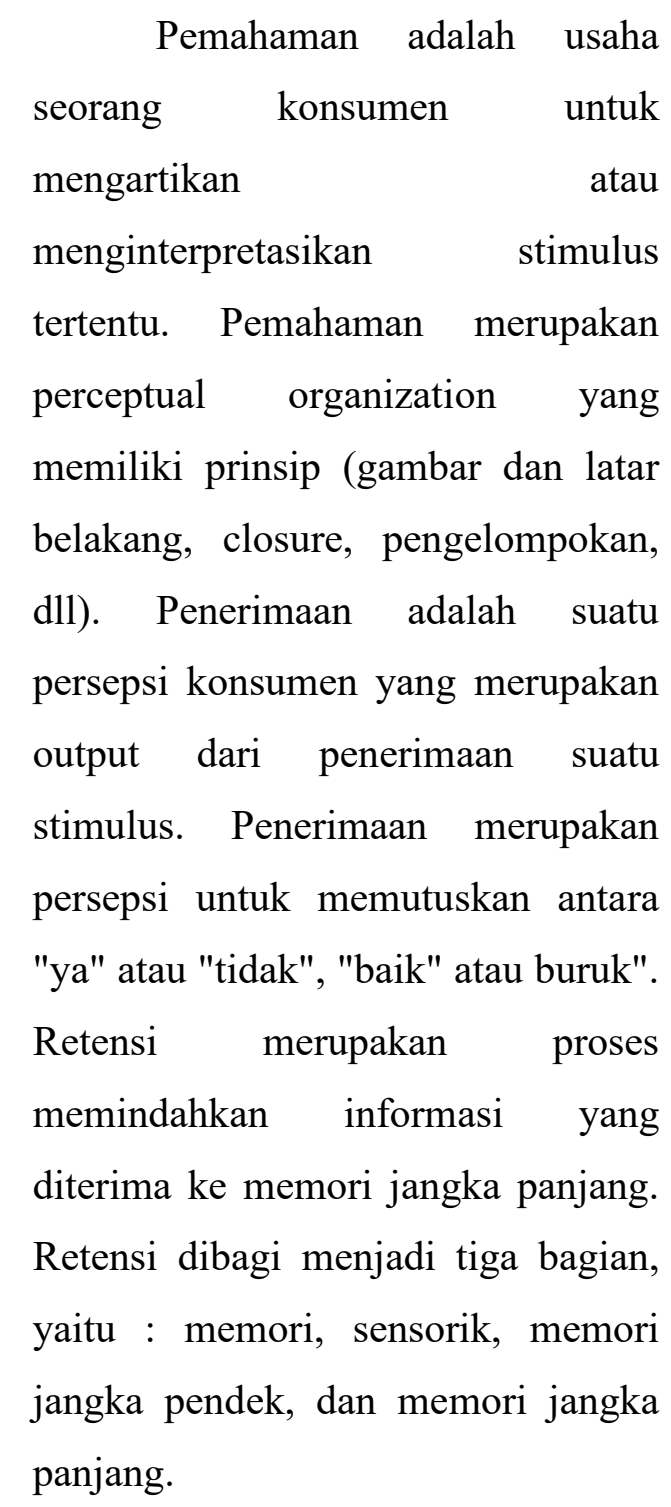

\section{B. Landasan Teori}

Persepsi Konsumen.

Persepsi konsumen adalah
proses seorang konsumen untuk
mengorganisasikan dan mengartikan
kesan dari pancaindra dalam tujuan
untuk memberi arti dalam
lingkungan mereka. Persepsi
konsumen penting dipelajari karena

perilaku konsumen didasarkan oleh persepsinya tentang kenyataan dan bukan kenyataan.

$$
\text { Persepsi terhadap sesuatu }
$$
berasal dari interaksi antara dua faktor yaitu :

a. Faktor stimulus, yaitu karakteristik secara fisik, seperti ukuran, berat, warna, atau bentuk. Tampilan suatu produk baik kemasan maupun karakteristik akan mampu menciptakan rangsangan pada indra kemanusiaan sehingga mampu menciptakan suatu persepsi mengenai produk yang dilihatnya.

b. Faktor individu yang termasuk proses di dalamnya bukan hanya pada pancaindra, melainkan juga pada proses pengalaman yang serupa dan dorongan utama serta harapan dari individu.

Persepsi seseorang juga melalui proses seleksi. Seleksi adalah proses memilih dan menentukan marketing stimuli karena setiap individu adalah unik dalam kebutuhan, keinginan, pengalaman, sikap, dan karakter pribadi masingmasing

Dalam seleksi terdapat beberapa proses, yaitu : 
a. Selective exposure, yaitu konsumen secara efektif mencari pesan menemukan kesenangan atau simpati secara aktif menghindari kesakitan atau ancaman pada sisi lainnya. Secara efektif, ia membuka dirinya pada iklan yang menenteramkan hatinya mengenai kebijakan tentang kepuasan pembeliannya

b. Selective attention, yaitu konsumen mengadakan transaksi pemilihan yang bagus dengan tujuan perhatian mereka diberikan pada rangsangan komersial. la mempunyai kesadaran tinggi terhadap rangsangan yang sesuai dengan minat dan kebutuhannya. Dengan demikian konsumen dapat mengingat iklan untuk produk yang dapat memuaskan kebutuhannya dan mengabaikan yang tidak mereka butuhkan.

c. Perceptual defence, yaitu konsumen secara bawah sadar menyaring rangsangan yang ia temukan sebagai ancamanpsikologikal meskipun telah terdapat pembukaan Jadi, ancaman atau sebaliknya, rangsangan yang merusak mungkin lebih sedikit diterima secara sadar daripada rangsangan netral pada level pembukaan yang sama.

d. Perceptual blocking, yaitu konsumen melindungi dirinya dari rangsangan yang mereka anggap negatif dan mempunyai pengaruh buruk bagi dirinya.

\section{Karakteristik}

Seseorang Mempengaruhi Persepsi. Persepsi dapat dipengaruhi oleh karakter seseorang yang dipengaruhi oleh halhal sebagai berikut :

a. Attitudes : dua individu yang sama, tetapi mengartikan sesuatu yang dilihat berbeda satu yang lain.

b. Motives : kebutuhan yang tidak terpuaskan yang mendorong individu memiliki pengaruh yang kuat terhadap persepsinya.

c. Interests : fokus dari perhatian kita dipengaruhi oleh minat kita karena minat seseorang berbeda satu dan yang lain. Yang diperhatikan oleh seseorang dalam suatu situasi dapat berbeda satu dan yang lain dan dapat berbeda dari yang dirasakan oleh orang lain.

d. Experiences : fokus karakter individu yang berkaitan dengan pengalaman masa lalu, seperti minat 
atau interes individu. Seseorang individu merasakan pengalaman masa lalu pada suatu yang dikaitkan dengan hal yang terjadi saat ini.

e. Expectations : ekspektasi dapat mengubah persepsi Individu dalam melihat yang mereka harapkan dari yang terjadi saat ini.

Faktor-Faktor Yang Mempengaruhi Persepsi.

Faktor yang mempengaruhi persepsi adalah penglihatan dan sasaran yang diterima dan situasi persepsi terjadi penglihatan. Tanggapan yang timbul atas rangsangan dipengaruhi sifat-sifat individu yang melihatnya. Sifat yang dapat memengaruhi persepsi, yaitu :

a. Sikap, yaitu memengaruhi positif atau negatif tanggapan yang akan diberikan seseorang.

b. Motivasi, yaitu hal yang mendorong seseorang mendasari sikap tindakan yang dilakukannya.

c. Minat, yaitu faktor lain yang membedakan penilaian seseorang terhadap suatu hal atau obyek tertentu, yang mendasari kesukaan ataupun ketidaksukaan terhadap obyek tersebut. d. Pengalaman masa lalu, yaitu dapat memengaruhi persepsi seseorang karena akan menarik kesimpulan yang sama dengan yang pernah dilihat dan didengar

e. Harapan, yaitu memengaruhi persepsi seseorang dalam membuat keputusan, akan cenderung menolak gagasan, ajakan, atau tawaran yang tidak sesuai dengan yang kita harapkan.

f. Sasaran, yaitu memengaruhi penglihatan yang akhirnya akan memengaruhi persepsi

a. Situasi atau keadaan sekitar sekitar kita atau sekitar sasaran yang turut memengaruhi persepsi. Sasaran atau benda yang sama yang kita lihat dalam situasi yang berbeda akan menghasilkan persepsi yang berbed pula.

\section{Identifikasi dan Perumusan}

Masalah.

Dari uraian di atas, dan melalui identifikasi secara riil maka muncul adanya permasalahan sebagai berikut:

"Bagaimana upaya yang dilakukan
dalam rangka memberikan 
pemahaman kepada kelompok masyarakat yang mempunyai kegiatan usaha bisnis mikro atau home industri yang pada umumnya dikelola oleh para ibu-ibu di Desa Jatisari, Kecamatan Jenggawah melalui upaya peningkatan usaha bisnis di Era Revolusi Industri 4.02".

\section{E. Tujuan dan manfaat program}

Kegiatan sosialisasi pengabdian dengan Judul : adalah "PENGOLAHAN INFORMASI

DAN PERSEPSI KONSUMEN DI ERA REVOLUSI INDUSTRI 4.0", memiliki beberapa tujuan dan manfaat khususnya bagi para peserta sebagai usaha bisnis mikro atau home industri, yaitu :

a) Memberikan motivasi dan semangat kepada para pelaku usaha bisnis sehingga tumbuh pemahaman, kesadaran dan ketertarikan secara pribadi maupun kelompok untuk menekuni usahanya di era revolusi Industri 4.0.

b) Meningkatkan kerjasama antar pemilik usaha mikro atau home industri sebagai pelaku usaha bisnis dengan menindaklanjuti hasil sosialisasi sebagai upaya mengelola usahanya secara berkelanjutan

c) Masing-masing pelaku usaha bisnis mikro atau home industri untuk melakukan pembenahan seperti: pengawasan dan pengendalian secara cermat atas produk-produk yang dihasilkan oleh usahanya sehingga memiliki kualitas produk dan harapan para konsumen.

\section{F. Deskripsi Program}

Pelaksanan Kegiatan.

Program pengabdian yang digagas pada periode ini adalah PENGOLAHAN INFORMASI DAN PERSEPSI KONSUMEN DI ERA REVOLUSI INDUSTRI 4.0". Adapun tempat lokasi dan jadwal pelaksanaan kegiatan pengabdian pada masyarakat, yaitu :

Desa Jatisari, Kecamatan Jenggawah. :Hari Jumat, 26 April 2019. : 19.00 WIB - sampai dengan selesai.

a) Peserta : Kelompok Usaha Mikro 9 orang dengan berbagai jenis usaha.

b) Sosialisasi dengan metode pemaparan materi.

c) Tanya jawab dan diskusi. 
d) Diikuti oleh perangkat atau aparat Desa Jatisari, Sdr. Juriyanto, SAP jabatan Sekretaris Desa Jatisari.

\section{G. Evaluasi pengabdian}

Pelaksanaan sosialisasi.

a) Berdasarkan kesepakatan bersama antara narasumber pemateri) pengabdian dosen dengan para peserta dalam hal ini pemilik usaha bisnis mikro (home industri), mengingat jika diadakan pada siang hari terganggu dengan aktivitas usahanya maka pelaksanaan diselenggarakan pada malam hari.

b) Pelaksanaan pengabdian dosen di Desa Jatisari bersamaan dengan pelaksanaan KKN mahasiswa STIA Pembangunan Jember, dan kemudian pelaksanaannya difasilitasi oleh para mahasiswa tersebut.

c Pelaksanaan sosialisasi disamping diikuti oleh para pemilik usaha bisnis mikro juga dihadiri oleh perangkat desa yang dalam hal ini diwakili oleh Sdr. Juriyanto, SAP dan jabatan sebagai Sekretaris Desa Jatisari.

Evaluasi. a) Kehadiran peserta 9 (sembilan) orang dan pada umumnya diikuti oleh para ibu-ibu sebagai pemilik usaha bisnis mikro atau home industri.

b) Materi sosialisasi dapat diterima karena sangat sesuai dengan harapan, keinginan, dan kepentingan para peserta.

c) Melalui tanya jawab dan diskusi yang antusias diikuti secara seksama oleh para peserta sampai acara kegiatan sosialisasi berakhir.

d) Pada akhir diskusi diputuskan adanya perlu ditindak lanjuti dengan pendekatan kepada BLK Kabupaten Jember.

\section{H. Hasil Capaian Kegiatan}

Target Pencapaian

Adapun target sosialisasi: Program pengabdian yang digagas pada periode ini adalah "PENGOLAHAN INFORMASI DAN PERSEPSI KONSUMEN DI ERA REVOLUSI INDUSTRI 4.0". yaitu :

a) Meningkatkan pemahaman, ketertarikan dan kesungguhan untuk lebih mengenal akan pentingnya usaha yang telah ditekuni sebagai 
upaya meningkatkan kesejahteraan keluarga melalui usaha bisnis kewirausahaan yaitu usaha mikro atau home industri.

b) Meningkatkan pengetahuan mengenai ketertarikan para konsumen terhadap produk yang diolah oleh para produsen atau pemilik usaha bisnis kewirausahaan atau produk yang dihasilkan dari usaha home industri

c) Meningkatkan usaha yang harus dilakukan mengenai jenis produk yang dihasilkan disamping dari segi kualitas juga perlu diperhatikan dalam hal bentuk kemasan

Tindak lanjut pelaksanaan sosialisasi.

a) Melalui sosialisasi program tersebut telah dilakukan tanya jawab dengan peserta seperti: cara meningkatkan kualitas produk ; cara mengupayakan pengembangan jenis usaha maupun jenis produk

b) Solusi dan tindak lanjut perlu dilakukan dengan cara : diminta peran aparat desa atau perangkat Desa Jatisari untuk ikut serta membantu mewujudnyatakan harapan dan keinginan pemilik
Usaha Mikro atau home industri yang ada di wilayah Desa Jatisari melalui pendekatan dengan pihak BLK (Balai Lembaga Keterampilan) Kabupaten Jember.

\section{DAFTAR PUSTAKA}

Armawan, D. E. (2004). Perilaku Konsumen: Analisis Model Keputusan. Yogyakarta: Universitas Atmajaya.

Awaliyah, Ratih Fadlilah (2010). Analisis Pengaruh Persepsi Konsumen dan Bonus Dalam Kemasan Terhadap Keputusan Pembelian. Jakarta: Universitas Islam Negeri Syarif Hidayatulah

Basu Swastha, I. (2005). Manajemen Pemasaran Modern. Yogyakarta: Liberty.

H Nandan Ahmad Hidayat, S. M. (2015). Pengaruh persepsi terhadap keputusan pembelian melalui motivasi konsumen. Investasi Fakultas Ekonomi UnWir, 1(1), 19-35. 
Husein, U. (2003). Riset Pemasaran dan Perilaku Konsumen. Jakarta: Gramedia Pustaka Umum.

Husein, U. (2004). Metode Penelitian untuk Skripsi dan Tesis Bisnis. Jakarta : Rajawali Press.

James F Engel, R. D. (1994). Perilaku Konsumen. Jakarta: Bainarupa Aksara.

Keegan, K. (1997). Manajemen Pemasaran Global. Jakarta: PT Prenhallindo. (2014). Diambil kembali dari Molecular Recipes: http://www.molecularrecipes. com/molecul ar-mixologyclass/

Kotler, P. (2002). Manajemen Pemasaran Edisi Milenium Jilid 2. Jakarta: PT Prenhallindo

Oktavianus Taroreh, R. J. (2015). Pengaruh persepsi konsumen dan kepercayaan terhadap penggunaan jasa asuransi pada asuransi jasa manado. EMBA, 3(3), 312- 321. 